rate variability analysis in full-term infants: spectral indices for study of neonatal cardiorespiratory control. Pediatr Res 26:188-195

37. Curzi-Dascalova L, Clairambault J, Kauffmann F, Médigue C, Peirano P 1991

Cardio-respiratory variability and development of sleep state organisation.

In: Gaultier C, Escourrou P, Curzi-Dascalova L (eds) Sleep and Cardiorespiratory Control. John Libbey, London, pp 155-162

38. Eiselt M, Curzi-Dascalova L, Clairambault J, Kauffmann F, Médigue C, Peirano P 1993 Heart rate variability in low-risk prematurely born infants reaching the normal term: a comparison with full-term newborns. Early Hum Dev 32:183-195

39. Peirano P, Monod N 1992 Delayed developmental patterns of heart rate modulation during sleep states in small-for-gestational age infants. J Sleep Res 1(suppl):174(abstr)

40. Schechtman VL, Harper RM, Kluge KA 1989 Development of heart rate variation over the first 6 months of life in normal infants. Pediatr Res 26:343-346

\title{
Announcement
}

\section{International Congress of Pediatric Dermatology}

The VII International Congress of Pediatric Dermatology will be held in Buenos Aires, Argentina, from September 26th to October 1st, 1994. The main themes will be Atopic Dermatitis, Nutritional Disorders, AIDS, and Genodermatoses. For further information, please contact Dr. Adrián Pierini, President, VII International Congress of Pediatric Dermatology, Arenales 1446 Ap. 1 B, (1061) Buenos Aires, Argentina, phone (54.1) 8144068, fax (54.1) 812-9255. 